\title{
Rapid Detection of Type 2 Porcine Reproductive and Respiratory Syndrome Virus by a Duplex Reverse Transcription Insulated Isothermal PCR on a Field-Deployable System
}

Hung-Chih Kuo', Dan-Yuan Lo', Chiu-Lin Chen ${ }^{1}$, Chien-Hsien Lee ${ }^{2}$, Yu-Han Shen², Yung-Long Tsai ${ }^{2}$, Pei-Yu Alison Lee ${ }^{2 *}$ and Hsiao-Feng Grace Chang ${ }^{2}$

${ }^{1}$ Yunlin-Chiayi-Tainan of Animal Disease Diagnostic Center, College of Veterinary Medicine, National Chiayi University, Chiayi, Taiwan

${ }^{2}$ GeneReach Biotech, Taichung, Taiwan

\begin{abstract}
Porcine reproductive and respiratory syndrome virus (PRRSV) is an important porcine pathogen globally. Reverse transcription-polymerase chain reaction (RT-PCR) for PRRSV detection is an important tool for disease management and control. Clinical sensitivity of RT-PCR for PRRSV detection is compromised to a certain degree by the high genetic diversity in the PRRSV genome. A duplex RT-insulated isothermal PCR (RT-iiPCR) for the North America lineage of PRRSV (PRRSV-NA) has been developed by targeting both ORF6 and ORF7 to increase test inclusivity. In this study, its limit of detection $95 \%$ was determined to be about 5 genome equivalents per reaction by testing a serial dilution of in-vitro transcribed RNA. The PRRSV-NA duplex RT-iiPCR was compared with an ORF7 real-time RT-PCR (rRT-PCR) published previously for the evaluation of analytical and clinical performance. Both tests did not react with seven common swine pathogens. The two methods had similar detection endpoints for viral RNA of two PRRSV-NA isolates. Further tests with 187 swine samples showed that 14 of the 90 rRT-PCR-negative and 2 of the 97 rRT-PCR-positive samples were positive and negative by the duplex RT-iiPCR, respectively. The two methods had $91.44 \%$ agreement (95\% confidential interval: $87.26-95.62 \%, \mathrm{k}=0.83$ ). Repeat testing could not resolve 13 of the discrepant samples (all negative by rRT-PCR and positive by RT-iiPCR). Further RT-nested PCR analysis and DNA sequencing analysis of the ORF7 region supported that the target RNA was present in these samples. Therefore, the PRRSV-NA duplex RT-iiPCR appeared to have higher clinical sensitivity than the reference rRT-PCR. Working on a field-deployable device, the PRRSV-NA duplex RT-iiPCR has potential to serve as a fast and sensitive tool for PRRSV detection at points of need.
\end{abstract}

Keywords: PRRSV; Reverser transcription-insulated isothermal PCR; RT-iiPCR; Molecular detection; Field-deployable; Point of need

\section{Introduction}

Infection of porcine reproductive and respiratory syndrome virus (PRRSV) can lead to decreased pork production, and the costs for disease management were estimated \$664 million annually in the USA in 2011 $[1,2]$. PRRSV, a member of genus Arterivirus, family Arteriviridae, is an enveloped virus containing a positive single-stranded RNA of approximately $15 \mathrm{~kb}$, which encodes 11 open reading frames (ORFs). ORF1a and ORF1b encode the nonstructural proteins, Nsp1 $\alpha, N s p 1 \beta$, and Nsp2 to -12 [3]; ORF2 to ORF7 encode the structural proteins, GP2, E, GP3, GP4, GP5, M, and N [4]. PRRSV evolves rapidly and is divided into two genotypes sharing only about $60 \%$ nucleotide identity: the type 1 European lineage (PRRSV-EU, prototype the Lelystad strain) and the type 2 North American lineage (PRRSV-NA, prototype the VR-2332 strain) [5-8]. PRRSV-NA is prevalent in North America, South America, and Asia; and has also been found in Europe in recent years [8-12].

PRRSV can infect pigs of all ages. Its clinical symptoms include mild to severe respiratory syndromes in nursery-grown pigs, and reproductive failures characterized by infertility, late fetal mummification, abortions, stillbirths, and/or weak piglets $[9,13]$. Most importantly, PRRSV infection has been associated with the complicated porcine respiratory disease complexes [13]. Although various modified-live and inactivated vaccines are commercially available in many countries, their protection efficacy was limited to infection by PRRSV strains closely related to the vaccine strain, making the control of PRRS difficult $[9,14]$. Therefore, adoption of strict biosecurity measures to help avoid or reduce the introduction and transmission of PRRSV plays an important role in the control and eradication of PRRSV; sensitive and specific detection of the etiological agent is crucial to these measures $[15,16]$.

Several methods, including serological tests, virus isolation, and reverse transcription polymerase chain reaction (RT-PCR), are available for to help follow the status of PRRSV infection. The immunoassays, such as ELISA tests, for PRRSV-specific antibody have been commonly used to follow the immunization status of the pigs. Detection of the PRRSV by virus isolation is time-consuming and requires specific facility, technician, and cell line; furthermore, not all PRRSVs can be isolated. With high sensitivity and specificity, the RTPCR methodology has been accepted for PRRSV detection recently [9]. The RT-PCR assays for PRRSV detection reported so far were designed to target either the ORF6 or ORF7 gene [17-22], the regions found to be the most conserved among the available PRRSV sequences [23].

*Corresponding author: Pei-Yu Alison Lee, GeneReach Biotech, Keyuan Second Road, Central Taiwan Science Park, Taichung, Taiwan, Tel: 886-424639869; Fax: 886-4-24638255; E-mail: peiyu329@genereachbiotech.com

Received December 28, 2016; Accepted January 16, 2017; Published January 17,2017

Citation: Kuo HC, Lo DY, Chen CL, Lee CH, Shen YH, et al. (2017) Rapid Detection of Type 2 Porcine Reproductive and Respiratory Syndrome Virus by a Duplex Reverse Transcription Insulated Isothermal PCR on a Field-Deployable System. J Vet Sci Technol 8: 415. doi: 10.4172/2157-7579.1000415

Copyright: (c) $2017 \mathrm{Kuo} \mathrm{HC}$, et al. This is an open-access article distributed under the terms of the Creative Commons Attribution License, which permits unrestricted use, distribution, and reproduction in any medium, provided the original author and source are credited. 
Citation: Kuo HC, Lo DY, Chen CL, Lee CH, Shen YH, et al. (2017) Rapid Detection of Type 2 Porcine Reproductive and Respiratory Syndrome Virus by a Duplex Reverse Transcription Insulated Isothermal PCR on a Field-Deployable System. J Vet Sci Technol 8: 415. doi: 10.4172/21577579.1000415

Nevertheless, PRRSV mutates quickly and has a high degree of genetic diversity [24]. False-negative results in RT-PCR tests due to sequence variations in the primer and probe target areas have been reported. Consequently, the inclusion of more than one PRRSV RT-PCR test was recommended by OIE for PRRSV detection [9,25].

A duplex RT-insulated isothermal PCR (RT-iiPCR) was developed recently for PRRSV-NA (POCKIT ${ }^{\mathrm{TM}}$ PRRSV-NA Reagent Set, GeneReach Biotech, Taichung, Taiwan) to increase the strain coverage for PRRSV detection by RT-PCR. It was designed to target two of the most conserved regions found in the ORF6 and ORF7 genes in the PRRSV genome [23]. Furthermore, in iiPCR, natural liquid convection established in a capillary tube can cycle the reaction components sequentially through different temperature zones to achieve the 3 stages (denaturation, annealing, and extension) of PCR [26-28]. Consequently, the annealing step is not done at a fixed temperature in iiPCR, allowing primers and probes to bind to sequences with minor mismatches [29]. Clinical performance of various iiPCR for various bacterial and viral pathogens in companion animals, livestock animals, and aquaculture animals, food safety, and health care has been demonstrated to be comparable to that of the reference nested PCR, real-time PCR, and/or virus isolation method [28,30-41]. In several cases, clinical sensitivity slightly higher than that of the reference realtime PCR methods was observed for targets with notable sequence variations; clinical specificity can be maintained by careful design of the primer and probe $[36,42-44]$.

Additionally, the iiPCR works on a field-deployable device, the POCKIT $^{\mathrm{TM}}$ Nucleic Acid Analyzer (POCKIT ${ }^{\mathrm{TM}}$; GeneReach, Taichung, Taiwan), which is compact $(28 \times 25 \times 8.5 \mathrm{~cm}, \mathrm{~W} \times \mathrm{D} \times \mathrm{H})$ and lightweight $(2.1 \mathrm{~kg})$. Automatically interpreted results are generated within one hour. The regent is ready in a lyophilized format and minimal steps are involved in reaction assembly. Essentially, the iiPCR method is ready in a format for point-of-need applications to facilitate efficient biosecurity management and timely disease control.

In this study, analytical and clinical performance of the PRRSVNA duplex RT-iiPCR on the POCKIT ${ }^{\mathrm{TM}}$ device was evaluated and compared to a previously published rRT-PCR which was also routinely used in a diagnostic laboratory.

\section{Materials and Methods}

\section{Microorganisms and clinical samples}

One PRRSV Taiwan isolate (CH18-2) and a VR-2332-derived PRRSV-NA vaccine (Ingelvac PRRS ${ }^{\oplus}$ MLV, Boehringer Ingelheim Vetmedica, Saint Joseph, MO, USA) were used in the sensitivity comparison study. Sequencing analysis showed that $\mathrm{CH} 18-2$ was closely related to the previously reported PRRSV-NA MD001 strain found in Taiwan (data no shown); it was grouped into the lineage 3 of PRRSV based on its ORF5 sequence (maximum-likelihood analysis [TamuraNei model] with bootstrap analysis of 1000 replicates). The exclusivity test panel included PRRSV-EU (AMERVAC ${ }^{\circledast}$ PRRS, Laboratorios Hipra S.A., Amer, Spain), porcine circovirus type 2 (PCV2; Circovac ${ }^{\oplus}$, Merial, Lyon, France), Japanese encephalitis virus (JEV; SUIGEN ${ }^{\circ}$ Swine Japanese Encephalitis Live Virus Vaccine-at Strain, SBC Virbac Biotech, Kaohsiung City, Taiwan), pseudorabies virus (PRV; SUIGEN ${ }^{\star}$ Swine Pseudorabies Gene Deleted Live Vaccine, SBC Virbac Biotech), classic swine fever virus (CSFV; Dried Lapinized Hog Cholera Vaccine, Animal Health Research Institute, Council of Agriculture, New Taipei City, Taiwan), porcine parvovirus (PPV; PORCILIS ${ }^{\circ}$ PARVO, MSD Animal Health, Kenilworth, NJ, USA), and Mycoplasma hyopneumoniae (Ingelvac MycoFLEX ${ }^{\oplus}$, Boehringer Ingelheim Vetmedica, Saint Joseph, MO, USA). The clinical performance studies included 130 serum samples from diseased pigs and 57 postmortem lung tissues from animals with respiratory symptoms collected for surveillance or diagnostic purposes in Taiwan in 2016.

\section{In vitro transcription}

A linearized plasmid template containing the consensus sequences of ORF6 (nt 14285 - 14809, GenBank accession number KP89034) and ORF7 (nt 1 - 372, GenBank accession number JX046380) downstream of a T7-promoter was synthesized (Shanghai Generay Biotech, Shanghai, China). The consensus sequences were derived from alignment analyses of 792 ORF6 and 1168 ORF7 sequences. From this plasmid, an artificial ORF6/ORF7 RNA was produced by in vitro transcription (IVT) by using the MEGAscript ${ }^{\oplus}$ T7 Kit (Thermo Fisher Scientific, Carlsbad, CA). RNA concentrations were calculated from OD260 readings measured by a NanoDrop 2000 spectrophotometer (Thermo Fisher Scientific, Wilmington, DE) according to the following formula:

$$
\text { No. of RNA molecules } / \mu \mathrm{l}=\frac{\text { Avogadro number } \left.\left(6.022 \times 10^{23}\right) \times \text { RNA concentration }(\mathrm{g} / \mu \mathrm{l})\right)}{(\text { RNA molecular weight }(\mathrm{g})) .}
$$

The RNA was aliquoted and stored at $-80^{\circ} \mathrm{C}$ until use; dilutions were made in $40 \mathrm{ng} / \mu \mathrm{l}$ of yeast tRNA.

\section{Nucleic extraction}

Nucleic acid extraction was performed with the taco ${ }^{\mathrm{ma}}$ DNA/ RNA Extraction Kit (GeneReach Biotech) on $\operatorname{taco}^{\text {Tw }}$ mini Nucleic Acid Automatic Extraction System (taco ${ }^{\text {тx }}$ mini; Gene Reach Biotech) according to the manufacturer's instructions. For the lung tissue, 80 $\mathrm{mg}$ was homogenized in $500 \mu \mathrm{L}$ phosphate-buffered saline in a taco ${ }^{\mathrm{TM}}$ Prep (GeneReach Biotech) and centrifuged at 12,000 x g for $5 \mathrm{~min}$. After the wells of the extraction plate were filled with the designated buffers, $200 \mu \mathrm{L}$ of the serum or the supernatant from homogenized lung tissues were loaded to the first well of the extraction plate. The plate was subsequently loaded into a taco ${ }^{\mathrm{Tx}}$ mini device for automatic nucleic acid extraction. The nucleic acids were eluted individually in $200 \mu \mathrm{L}$ Eluting Buffer, transferred to fresh tubes, and stored at $-70^{\circ} \mathrm{C}$ for later use.

\section{RRSV duplex RT-iiPCR}

The PRRSV-NA duplex RT-iiPCR (POCKIT ${ }^{\mathrm{TM}}$ PRRSV Detection Kit) targeted both the ORF6 and ORF7 genes of PRRSV-NA; their amplicons were detected by the $550-\mathrm{nm}$ and $520-\mathrm{nm}$ channels, respectively, in the POCKIT ${ }^{\mathrm{TM}}$ device. Briefly, the lyophilized reagent was reconstituted with $50 \mu \mathrm{L}$ Premix Buffer B and mixed with $5 \mu \mathrm{L}$ nucleic acid extract. Subsequently, $50 \mu \mathrm{L}$ of the final mixture were transferred to an R-tube ${ }^{\mathrm{TM}}$ (GeneReach Biotech) which was loaded into a POCKIT ${ }^{\mathrm{TM}}$ device. Qualitative results were generated by the builtin algorithm and shown on the display screen within 1 hour. Samples generating positive signals from either ORF6 or ORF7 marker were considered PRRSV positive.

\section{PRRSV real-time RT-PCR}

The reference PRRSV-NA rRT-PCR (Table 1) [17,45] was routinely used as a tool to facilitate PRRSV diagnosis at the Animal Disease Diagnostic Center, National Chiayi University. It targeted the ORF7 gene. The $25-\mu \mathrm{L}$ reaction contained 1x PCR Reaction Buffer (BioMi, Taichung, Taiwan), $0.5 \mathrm{mM}$ dNTP, $0.25 \mu \mathrm{M}$ forward primer, $0.5 \mu \mathrm{M}$ reverse primer, $0.2 \mu \mathrm{M}$ probe, $0.3 \mu \mathrm{M}$ ROX, 60 units of MMLV reverse 
Citation: Kuo HC, Lo DY, Chen CL, Lee CH, Shen YH, et al. (2017) Rapid Detection of Type 2 Porcine Reproductive and Respiratory Syndrome Virus by a Duplex Reverse Transcription Insulated Isothermal PCR on a Field-Deployable System. J Vet Sci Technol 8: 415. doi: 10.4172/21577579.1000415

transcriptase (BioMi), 2 units of Taq polymerase (BioMi), and $2 \mu \mathrm{L}$ of sample nucleic acids. The reaction was performed on an Applied Biosystems ${ }^{\oplus}$ Step One Plus ${ }^{\mathrm{TM}}$ system (Thermo Fisher Scientific) at $42^{\circ} \mathrm{C}$ for $30 \mathrm{~min}$ followed by 40 cycles of $93^{\circ} \mathrm{C}$ for $15 \mathrm{~s}$ and $60^{\circ} \mathrm{C}$ for $1 \mathrm{~min}$. A representative standard curve of the rRT-PCR analyses with a serial dilution of the ORF6/ORF7 IVT RNA had a linearity range between $10^{2}$ and $10^{6}$ copies with a slope of -3.21 (correlation coefficient, 0.99 ; y-intercept, 39.78; data not shown). All results that had a recorded threshold cycle $(\mathrm{Ct})$ value were considered PRRSV positive.

\section{PRRSV ORF7 RT-nested PCR and sequencing analysis}

To amplifying the target region of the PRRSV-NA rRT-PCR, a degenerate RT-nested PCR (Table 1) was designed and optimized to target the highly conserved sequences found in the 212 sequences of PRRSV-NA available in the GenBank database. Briefly, the $10-\mu \mathrm{L}$ solution containing the sample and $1 \mu \mathrm{M}$ random primers was heated to $80^{\circ} \mathrm{C}$ for $10 \mathrm{~min}$ and cooled immediately on ice. Next, the $20-\mu \mathrm{L}$ RT reaction containing $1 \times$ Reaction Buffer, $0.5 \mathrm{mM}$ dNTP, 200 units of MMLV reverse transcriptase (Thermo Fisher Scientific), and $10 \mu \mathrm{L}$ of the pretreated template was incubated at $37^{\circ} \mathrm{C}$ for 1 hour, $42^{\circ} \mathrm{C}$ for $30 \mathrm{~min}$, and $94^{\circ} \mathrm{C}$ for $5 \mathrm{~min}$. For both steps in the nested PCR, the 20$\mu \mathrm{L}$ reaction contained 1x PCR Reaction Buffer (BioMi), $0.125 \mathrm{mM}$ dNTP, $0.25 \mu \mathrm{M}$ each of the forward and reverse primers, 2 units of Taq polymerase (BioMi), and $2 \mu \mathrm{L}$ sample. The first PCR (n-f1 and n-r1 primers, Table 1) was performed with the following program: $95^{\circ} \mathrm{C}$ for $30 \mathrm{~s} ; 30$ cycles of $95^{\circ} \mathrm{C}$ for $20 \mathrm{~s}, 61^{\circ} \mathrm{C}$ for $20 \mathrm{~s}$, and $72^{\circ} \mathrm{C}$ for $40 \mathrm{~s}$; and $72^{\circ} \mathrm{C}$ for $5 \mathrm{~min}$. The program for the second PCR (n-f2 and n-r2 primers, Table 1) was $95^{\circ} \mathrm{C}$ for $30 \mathrm{~s} ; 30$ cycles of $95^{\circ} \mathrm{C}$ for $20 \mathrm{~s}, 56^{\circ} \mathrm{C}$ for $20 \mathrm{~s}$, and $72^{\circ} \mathrm{C}$ for $40 \mathrm{~s}$; and $72^{\circ} \mathrm{C}$ for $5 \mathrm{~min}$. The PCR products of the expected size were verified on a $2 \%$ agarose gel stained with ethidium bromide and sent to Genomics (Taipei, Taiwan) for DNA sequencing analysis. Phylogenetic trees were constructed by using the maximumlikelihood method by the MEGA 5 software [46].

\section{Statistical analysis}

Limit of detection 95\% (LOD95\%) of a reaction was determined by probit analysis at 95\% confidence interval by SPSS v14 (SPSS, Chicago, IL, USA). The 2 x 2 contingency tables were analyzed by kappa statistic using SPSS to determine the inter-rater agreement.

\section{Results}

\section{Analytical sensitivity of the PRRSV-NA duplex RT-iiPCR}

To assess the analytical sensitivity of the PRRSV-NA duplex RTiiPCR, a serial dilution of the ORF6/ORF7 IVT RNA was tested. The detection rates of the 100- (10/10), 50- (20/20), 20- (20/20), and 10copy $(20 / 20)$ reactions were $100 \%$; those of the 5-, 1-, and 0 -copy ones were 95\% (19/20), 25\% (5/20), and 0\% (0/24), respectively. Probit regression analysis determined that the LOD95\% of the reaction was about 5 genome equivalents per reaction.
The analytical sensitivity of the PRRSV-NA duplex RT-iiPCR for PRRSV RNA was compared to that of the reference PRRSV-NA rRT-PCR [17,45] using serial dilutions of the nucleic acid extracts of a Taiwan isolate (CH18-2) and a VR-2332-derived vaccine. The $100 \%$ endpoints of the duplex RT-iiPCR and the rRT-PCR were at the $10^{-5}$ and $10^{-4}$ dilution, respectively, with both samples (Table 2), demonstrating that the RT-iiPCR and the rRT-PCR had similar sensitivity for the viral RNA of the PRRSV isolates.

\section{Analytical specificity of PRRSV-NA duplex RT-iiPCR}

Analytical specificity of the PRRSV-NA duplex RT-iiPCR was verified with a PRRSV-EU strain, and CSFV, PCV2, PRV, PPR, JEV, and $M$. hyopneumoniae, whose infection also causes respiratory symptoms, production failure, and/or gross lesion in the lungs on infected animals. The PRRSV-NA duplex RT-iiPCR did not detect any of these pathogens.

\section{Clinical performance of the PRRSV-NA duplex RT-iiPCR}

The PRRSV-NA duplex RT-iiPCR was compared with the reference rRT-PCR to evaluate its clinical performance for the detection of PRRSV in swine samples. Totally, 130 sera and 57 lung tissues collected in Taiwan in 2016 were tested by the two methods in parallel. Among them, 97 were positive and 90 negative by the rRT-PCR; 109 were positive and 78 negative by the duplex RT-iiPCR (Tables S1 and 3a). Two of the 97 rRT-PCR-positive samples were negative by the RTiiPCR; notably, 14 of the 90 rRT-PCR negative samples were positive by the duplex RT-iiPCR. Based on these results, the agreement between the two assays was $91.44 \%$ (95\% confidential interval: $87.26 \%$ - 95.62\%; $\kappa=0.83$ ). Repeating tests by the two tests were performed to help resolve the discrepancy. Three of the samples (S29, S77, and S81) were positive by both methods ( $\mathrm{rRT}-\mathrm{PCR}, 1 / 5[\mathrm{Ct}=38.78], 2 / 5[\mathrm{Ct}=39.90,38.54]$, and $2 / 5$ [Ct=37.96, 37.55], respectively; duplex RT-iiPCR, $3 / 5,2 / 5$, and $2 / 5$, respectively); the other 13 specimens still showed discordant results after repeat testing (Table S2).

\section{RT-nested PCR and sequencing analysis of the discrepant samples}

An RT-nested PCR was established to amplify the target region of the rRT-PCR in ORF7 from the 13 samples. The results of the RTnested PCR can help resolve the discrepancies between the results of the rRT-PCR and RT-iiPCR methods, and the amplicons obtained, if any, were subjected to further sequencing analysis. Mutations at the primer/probe binding sites can lead to false-negative results in PCR assays $[9,25]$. RT-nested PCR products of the expected size and ORF7 sequences (nt 2-350, Figure 1) were obtained from all 13 samples, supporting that the samples were PRRSV positive. Sequencing analysis revealed that 1-3 mismatches were found in the forward primer, 1-2 mismatches in the probe, and 0-1 mismatches in the reverse primer sequences of the rRT-PCR assay. The phylogenetic tree generated from

\begin{tabular}{|c|c|c|c|}
\hline Reaction & Name & Nucleotide sequence (5' - 3') & position* \\
\hline \multirow{3}{*}{ rRT-PCR } & PRRSVf2 & GGGGAATGGCCAGYCAGTCAA & $14927-14947$ \\
\hline & PRRSVr2 & GCCAGRGGAAAATGKGGCTTCTC & $15061-15039$ \\
\hline & US probe & FAM-CTGGGYARGATYATCGCCCAGCA-BHQ1 & $14964-14986$ \\
\hline \multirow{4}{*}{ RT-nested PCR } & $\mathrm{n}-\mathrm{f} 1$ & GGCCCCTGCCCACCAC & $14704-14719$ \\
\hline & $n-r 1$ & GGCARACTRAACTCCACAGYGTAACT & $15208-15183$ \\
\hline & $\mathrm{n}-\mathrm{f} 2$ & ACCACGTYGAAAGTGCCG & $14715-14732$ \\
\hline & $n-r 2$ & AACTCCACAGTGTAACTTATYCTCCC & $15199-15174$ \\
\hline
\end{tabular}

*Nucleotide position is based on the sequence of the VR-2322 strain (GenBank accession no. U87392.3)

Table 1: Sequences of primers and probe used in the PRRSV-NA rRT-PCR and RT-nested PCR. 
Citation: Kuo HC, Lo DY, Chen CL, Lee CH, Shen YH, et al. (2017) Rapid Detection of Type 2 Porcine Reproductive and Respiratory Syndrome Virus by a Duplex Reverse Transcription Insulated Isothermal PCR on a Field-Deployable System. J Vet Sci Technol 8: 415. doi: 10.4172/21577579.1000415

Page 4 of 7

these nucleotide sequences suggested that the 13 PRRSV samples all belonged to the PRRSV-NA lineage (data not shown).

\section{Discussion and Conclusion}

Among the tools recommended by OIE for the detection of PRRSV (virus isolation, immunoassay, RT-PCR) [9], the PCR methodology is gaining momentum in recent years. However, testing with multiple PCR methods has been recommended to help mitigate the risks of false-negative results due to the high genetic variations found in the viral genome. The PRRSV-NA duplex RT-iiPCR was designed to amplify two of the most conserved regions found in the PRRSVNA sequences available in the GenBank database, i.e., in ORF6 and ORF7 genes, to help boost the detection inclusivity/sensitivity of the reaction for PRRSV-NA. Notably, 13 of the 90 rRT-PCR-negative samples reacted positively in the duplex RT-iiPCR test (Table S2). The positive RT-nested PCR results and sequencing analyses of these samples provided evidences for the presence of PRRSV RNA in the samples. After integrating the results of all tests, 111 PRRSV-positive samples were found; all were positive by the duplex RT-iiPCR and 13 of them were negative by the rRT-PCR (Tables 3b), implying that the duplex RT-iiPCR had higher clinical sensitivity (inclusivity) than the reference rRT-PCR. The fact that the annealing step was not carried out at a specific temperature may have also allowed the reaction to tolerate sequence mismatches to some extent in iiPCR.

Although the reference rRT-PCR contained degenerate primers and probes to be inclusive for as many strains of PRRSV as possible [17], significant numbers of mutations in the forward primer (1-3 mismatches) and/or probe binding sites (1 - 2 mismatches) were found in the 13 rRT-PCR false-negative samples. Similarly, mutations at the primer/probe binding sites caused by genetic variations led to the false-negative results in certain PRRSV real-time PCR assays $[9,25]$. Sequence mismatches could have decreased the binding efficiency between the oligonucleotides and the target sequences (Figure 1), leading to reduction in the melting temperatures $(\mathrm{Tm})$ and negative effects on the annealing step. For 12 of the 13 discrepant samples, substantial $\mathrm{Tm}$ reductions $\left(\sim 15-30^{\circ} \mathrm{C}\right)$ between the probe of the rRT-PCR and the target sequences were suggested by bioinformatics analysis ( $75 \mathrm{mM}$ monovalent ion and $3 \mathrm{mM} \mathrm{Mg}^{2+;}$ OLIGO 7 software; Molecular Biology Insights, Colorado Springs, CO, USA) [49]); for the one (L2) with minor probe $\mathrm{Tm}$ reduction $\left(\sim 8^{\circ} \mathrm{C}\right)$, significant $\mathrm{Tm}$ reductions in both primers were predicted. One base-pair mismatch in the probe biding site had substantial influence on the sensitivity of different real-time PCR tests for influenza virus and swine hepatitis E virus $[47,48]$.

Information of the PRRSV infection status is important for PRRSV control and elimination [15]. However, issues such as time-consuming procedures, carry-over contamination, and/or expensive equipment and special technicians have limited the application of conventional RT-PCR at points of need. The sensitive and specific iiPCR/ POCKITTM system described herein is a practical tool for settings with limited resources. The device can be powered on a rechargeable or car battery; the lyophilized reagent can be shipped without a cold chain and stored for up to two years in a refrigerator. Its protocols, involving only a couple of assembly steps, can be accomplished by any

\begin{tabular}{|c|c|c|c|c|c|c|c|}
\hline \multirow[t]{2}{*}{ Strain } & \multirow{2}{*}{ Dilution Factor } & \multicolumn{3}{|c|}{ rRT-PCR (Ct) } & \multicolumn{3}{|c|}{ duplex RT-iiPCR } \\
\hline & & test 1 & test 2 & test 3 & test 1 & test 2 & test 3 \\
\hline \multirow{5}{*}{$\begin{array}{l}\text { VR2332-derived } \\
\text { vaccine }\end{array}$} & $10^{2}$ & 29.54 & 29.74 & 29.69 & + & + & + \\
\hline & $10^{3}$ & 31.97 & 32.51 & 32.31 & + & + & + \\
\hline & $10^{4}$ & 36 & 37.01 & 35.56 & + & + & + \\
\hline & $10^{5}$ & - & - & - & + & + & + \\
\hline & $10^{6}$ & - & - & - & + & - & - \\
\hline \multirow{5}{*}{$\begin{array}{l}\text { Taiwan } \mathrm{CH} 18-2 \\
\text { isolate }\end{array}$} & $10^{2}$ & 29.5 & 29.11 & 29.09 & + & + & + \\
\hline & $10^{3}$ & 32.85 & 33.01 & 32.57 & + & + & + \\
\hline & $10^{4}$ & 37.13 & 35.42 & 38.74 & + & + & + \\
\hline & $10^{5}$ & - & 39.65 & - & + & + & + \\
\hline & $10^{6}$ & - & - & - & - & - & + \\
\hline
\end{tabular}

Table 2: Detection limit of the PRRSV-NA duplex RT-iiPCR: comparison with the rRT-PCR.

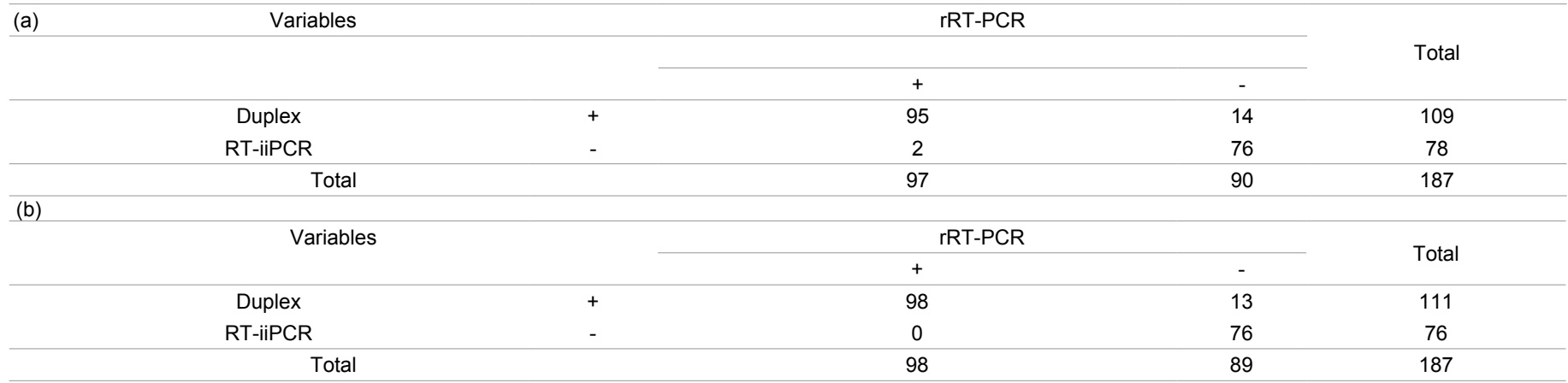

Table 3: A 2 × 2 contingency between the rRT-PCR and duplex RT-iiPCR for PRRSV-NA detection in swine samples. 
Citation: Kuo HC, Lo DY, Chen CL, Lee CH, Shen YH, et al. (2017) Rapid Detection of Type 2 Porcine Reproductive and Respiratory Syndrome Virus by a Duplex Reverse Transcription Insulated Isothermal PCR on a Field-Deployable System. J Vet Sci Technol 8: 415. doi: 10.4172/21577579.1000415

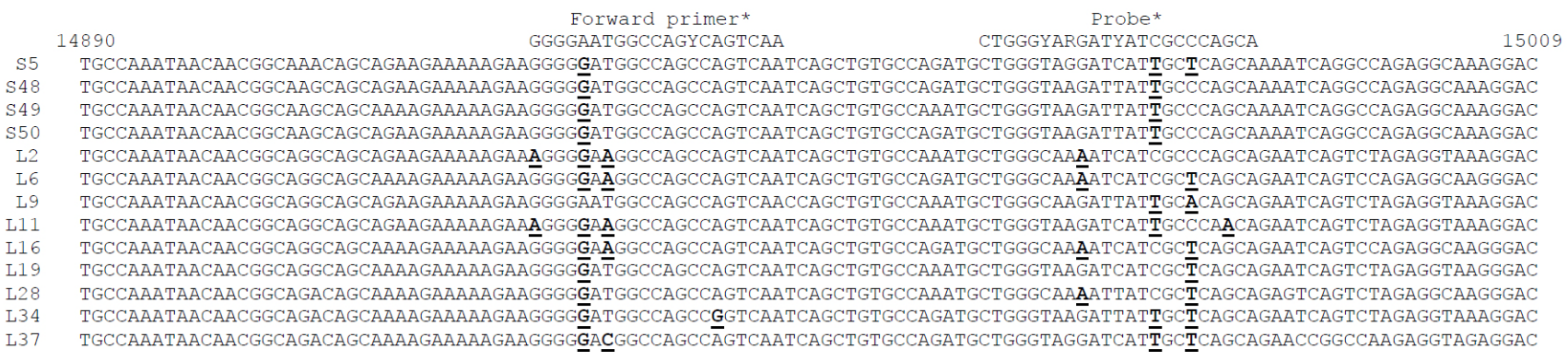

$5010 \quad$ GAGAAGCCMCATTTTCCYCTGGC 15129

CGGGCAAGAAAAATAAGAGGAAAAGCCCGGAGAAGCCACATTTTCCCCTGGCTACTGAAGATGACGTTAGGCACCACTTTACCCCTAGTGAGCGGCAATTGTGTCTGTCGTCAATCCAGA CGGGCAAGAAAGATAAGAGGAGAAGCCCGGAGAAGCCACATTTTCCTCTGGCCACTGAAGATGACGTTAGACACCACTTTACCCCTAGTGAGCGACAGTTGTGTCTGTCGTCAATCCAGA CGGGCAAGAAAGATAAGAGGAGAAGCCCGGAGAAGCCACATTTTCCTCTGGCCACTGAAGATGACGTTAGACACCACTTTACCCCCAGTGAGCGACAATTGTGTCTGTCGTCAATCCAAA CGGGCAAGAAAGATAAGAGGAGAAGCCCGGAGAAGCCACATTTTCCTCTGGCCACTGAAGATGACGTTAGACACCACTTTACCCCTAGTGAGCGACAGTTGTGTCTGTCGTCAATCCAGA CGGGAAAGAAAAACAAGAAGAAGAACCCGGAGAAGCCCCATTTTCCTCTAGCCACTGAAGATGACGTCAGGCATCACTTTACCCCTAGTGAGCGGCAATTATGTCTGTCGTCCATCCATA CGGGAAAGAAAATTAAGAAGAGAAACCCGGAGAAGCCCCATTTTCCTCTA GCTACTGAAGATGACGTCAGACACCACTTTACCCCTAGTGAGCGGCAATTATGTCTGTCGTCGATCCAGA CGGGGAATAGAATCAAGAAGAGAAACCCGGAGAAGCCCCATTTTCCTCTA CGGGAAGGAAAAATAAGAAGAAAAACCCGGAGAAGCCCCATTTTCCTCTGGCCACTGAAGATGACGTCAGGCATCATTTTACCCCTAGTGAGCGGCAGTTATGTCTGTCGTCAATCCATA CGGGAAAGAAAATTAAGAAGAGAAACCCGGAGAAGCCCCATTTTCCTCTAGCTACTGAAGATGACGTCAGACACCACTTTACCCCTAGTGAGCGGCAATTATGTCTGTCGTCGATCCAGA CGGCTAAGA CGGG CGGGAATGAGAAACAAGAAGAAAAACCCGGAGAAGCCCATTTTCCTCTGGCCACTGAAGATGACGTCAGACACCACTTTACCCCTAGTGAGCGACAACTATGTCTGTCGTCAATCCAAA

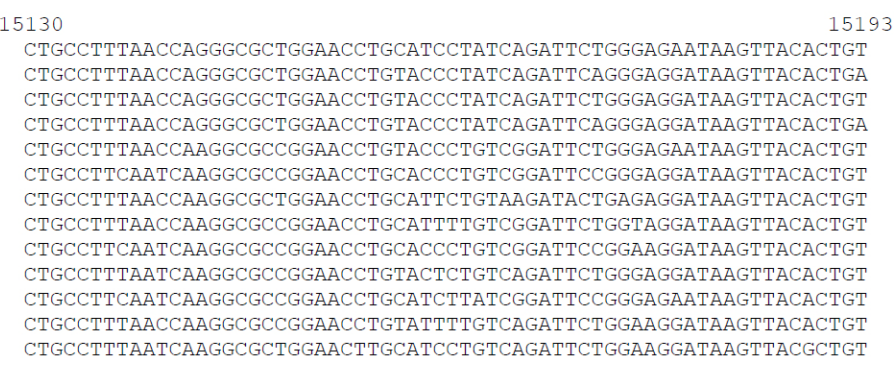

Figure 1: Sequence alignment of the ORF7 region of the 13 rRT-PCR-negative/ duplex RT-iiPCR-positive samples. Nucleotide positions were based on the sequence of the PRRSV-NA VR-2332 strain (GanBank accession no. U87392). *, rRT-PCR primer and probe sequences; bold and underlined, nucleotide different from that of the primer or probe sequence.

users with basic training. Implemented in a closed system, the system has relatively low risks of amplicon cross-contamination. The relatively inexpensive system can be performed at locations close to or at the pen side, reducing the turn-around time to facilitate timely implementation of the measures for the control and management of PRRSV infection.

A nucleic acid extraction step before PCR is generally required to remove the reaction inhibitors from the sample matrix [49]. A field-deployable automatic nucleic acid extraction method, namely $\operatorname{taco}^{\mathrm{TM}} \mathrm{mini}$, is available to help reduce the labor costs and increase the performance consistency of the procedure. This device can also be operated on rechargeable car battery. The protocol combining the $\operatorname{taco}^{\mathrm{TM}}$ mini with the POCKIT ${ }^{\mathrm{TM}}$ device can generate qualitative test results within 2 hours with minimal hands-on time.

With great analytical sensitivity and specificity, the PRRSV-NA duplex RT-iiPCR was shown to have higher clinical sensitivity than the reference rRT-PCR. Working on the field-deployable taco ${ }^{\mathrm{TM}} \mathrm{mini} /$ POCKIT $^{\mathrm{TM}}$ system in a rapid and user-friendly manner, this test can provide timely information on the status of PRRSV infection to facilitate efficient biosecurity and disease management in the swine industry.

\section{References}

1. Lunney JK, Benfield DA, Rowland RR (2010) Porcine reproductive and respiratory syndrome virus: an update on an emerging and re-emerging viral disease of swine. Virus Res 1: 1-6.

2. Holtkamp DJ, Kliebenstein JB, Neumann E, Zimmerman JJ, Rotto H, et al (2013) Assessment of the economic impact of porcine reproductive and respiratory syndrome virus on United States pork producers. J Swine Health Prod 2: 72-84.

3. Ropp SL, Wees CEM, Fang Y, Nelson EA, Rossow KD, et al. (2004) Characterization of emerging European-like porcine reproductive and respiratory syndrome virus isolates in the United States. J Virol 7: 3684-3703.

4. Stadejek T, Oleksiewicz M, Potapchuk D, Podgorska K (2006) Porcine reproductive and respiratory syndrome virus strains of exceptional diversity in eastern Europe support the definition of new genetic subtypes. J Gen Virol 7 : 1835-1841.

5. Allende R, Lewis T, Lu Z, Rock D, Kutish G, et al. (1999) North American and European porcine reproductive and respiratory syndrome viruses differ in nonstructural protein coding regions. J Gen Virol 2: 307-315.

6. Nelsen CJ, Murtaugh MP, Faaberg KS (1999) Porcine reproductive and respiratory syndrome virus comparison: divergent evolution on two continents. J Virol 1: 270-280

7. Forsberg $R$ (2005) Divergence time of porcine reproductive and respiratory syndrome virus subtypes. Mol Biol Evol 11: 2131-2134.

8. Brar MS, Shi M, Murtaugh MP, Leung FCC (2015) Evolutionary diversification of type 2 porcine reproductive and respiratory syndrome virus. J Gen Virol 7 : 
Citation: Kuo HC, Lo DY, Chen CL, Lee CH, Shen YH, et al. (2017) Rapid Detection of Type 2 Porcine Reproductive and Respiratory Syndrome Virus by a Duplex Reverse Transcription Insulated Isothermal PCR on a Field-Deployable System. J Vet Sci Technol 8: 415. doi: 10.4172/21577579.1000415

Page 6 of 7

\section{0-1580.}

9. OIE (2015) Porcine reproductive and respiratory syndrome: Manual of diagnostic tests and vaccines for terrestrial animals.(7), World Organisation for Animal Health (OIE), Paris, France.

10. Shi M, Lam TTY, Hon CC, Murtaugh MP, Davies PR, et al. (2010) Phylogenybased evolutionary, demographical, and geographical dissection of North American type 2 porcine reproductive and respiratory syndrome viruses. J Viro 17: 8700-8711

11. Shi M, Lam TTY, Hon CC, Hui RKH, Faaberg KS, et al. (2010) Molecular epidemiology of PRRSV: A phylogenetic perspective. Virus Res 1: 7-17.

12. Stadejek T, Stankevicius A, Murtaugh MP, Oleksiewicz MB (2013) Molecular evolution of PRRSV in Europe: Current state of play. Vet Microbiol 1: 21-28.

13. Lunney JK, Fang Y, Ladinig A, Chen N, Li Y, et al. (2016) Porcine Reproductive and Respiratory Syndrome Virus (PRRSV): Pathogenesis and interaction with the immune system. Annu Rev Anim Biosci 4: 129-154.

14. Chand RJ, Trible BR, Rowland RR (2012) Pathogenesis of porcine reproductive and respiratory syndrome virus. Curr Opin Virol 3: 256-263.

15. Rowland R, Morrison R (2012) Challenges and opportunities for the control and elimination of porcine reproductive and respiratory syndrome virus. Transbound Emerg Dis s1: 55-59.

16. Corzo CA, Mondaca E, Wayne S, Torremorell M, Dee S, et al. (2010) Contro and elimination of porcine reproductive and respiratory syndrome virus. Virus Res 1: 185-192.

17. Lurchachaiwong W, Payungporn S, Srisatidnarakul U, Mungkundar C Theamboonlers A, et al. (2008) Rapid detection and strain identification of porcine reproductive and respiratory syndrome virus (PRRSV) by real-time RTPCR. Lett Appl Microbiol 1: 55-60.

18. Lin CN, Lin WH, Hung LN, Wang SY, Chiou MT (2013) Comparison of viremia of type II porcine reproductive and respiratory syndrome virus in naturally infected pigs by zip nucleic acid probe-based real-time PCR. BMC Vet Res 1: $181-182$.

19. Chang CY, Deng MC, Wang FI, Tsai HJ, Yang CH, et al. (2014) The application of a duplex reverse transcription real-time PCR for the surveillance of porcine reproductive and respiratory syndrome virus and porcine circovirus type 2 . J Virol Methods 201: 13-19.

20. Egli C, Thür B, Liu L, Hofmann MA (2001) Quantitative TaqMan ${ }^{\circledR}$ RT-PCR for the detection and differentiation of European and North American strains of porcine reproductive and respiratory syndrome virus. J Virol Methods 1: 63-75.

21. Kleiboeker SB, Schommer SK, Lee SM, Watkins S, Chittick W, et al. (2005) Simultaneous detection of North American and European porcine reproductive and respiratory syndrome virus using real-time quantitative reverse transcriptase-PCR. J Vet Diagn Invest 2: 165-170.

22. Revilla-Fernández S, Wallner B, Truschner K, Benczak A, Brem G, et al. (2005) The use of endogenous and exogenous reference RNAs for qualitative and quantitative detection of PRRSV in porcine semen. J Virol Methods 1: 21-30.

23. Stevenson G, Torremorell M (2012) Porcine reproductive and respiratory syndrome virus (porcine Arterivirus): Diseases of swine. (10thedn). Blackwell, Ames, IA, USA.

24. Murtaugh MP, Stadejek T, Abrahante JE, Lam TT, Leung FCC (2010) The ever-expanding diversity of porcine reproductive and respiratory syndrome virus. Virus Res 1: 18-30.

25. Wernike K, Bonilauri P, Dauber M, Errington J, Le Blanc N, et al. (2012) Porcine reproductive and respiratory syndrome virus: Interlaboratory ring trial to evaluate real-time reverse transcription polymerase chain reaction detection methods. J Vet Diagn Invest 24: 855-866.

26. Chang HFG, Tsai YL, Tsai CF, Lin CK, Lee PY, et al. (2012) A thermally baffled device for highly stabilized convective PCR. Biotechnol J 5: 662-666.

27. Tsai YL, Wang HT, Chang HF, Tsai CF, Lin CK, et al. (2012) Development of TaqMan probe-based insulated isothermal PCR (iiPCR) for sensitive and specific on-site pathogen detection. PLoS ONE 9: e45278.

28. Tsai YL, Wang HC, Lo CF, Tang-Nelson K, Lightner D, et al. (2014) Validation of a commercial insulated isothermal PCR-based POCKITTM test for rapid and easy detection of white spot syndrome virus infection in Litopenaeus vannamei.
PLoS ONE 3: e90545.

29. Krishnan M, Ugaz VM, Burns MA (2002) PCR in a Rayleigh-Benard convection cell. Science 5594: 793.

30. Tsen HY, Shih CM, Teng PH, Chen HY, Lin CW, et al. (2013) Detection of Salmonella in chicken meat by insulated isothermal PCR. J Food Prot 8: 1322-1329.

31. Balasuriya UB, Lee PY, Tiwari A, Skillman A, Nam B, et al. (2014) Rapid detection of equine influenza virus H3N8 subtype by insulated isothermal RTPCR (iiRT-PCR) assay using the POCKIT ${ }^{\mathrm{T}}$ Nucleic Acid Analyzer. J Virol Methods 207: 66-72.

32. Wilkes RP, Tsai YL, Lee PY, Lee FC, Chang HF, et al. (2014) Rapid and sensitive detection of canine distemper virus by one-tube reverse transcriptioninsulated isothermal polymerase chain reaction. BMC Vet Res 10: 213.

33. Wilkes RP, Kania SA, Tsai YL, Lee PY, Chang HH, et al. (2015) Rapid and sensitive detection of feline immunodeficiency virus using an insulated isothermal PCR-based assay with a point-of-need PCR detection platform. J Vet Diagn Invest 4: 510-515.

34. Wilkes RP, Lee PY, Tsai YL, Tsai CF, Chang HH, et al. (2015) An insulated isothermal PCR method on a field-deployable device for rapid and sensitive detection of canine parvovirus type 2 at points of need. J Virol Methods 220 35-38.

35. Lung O, Pasick J, Fisher M, Buchanan C, Erickson A, et al. (2015) Insulated isothermal reverse transcriptase PCR (iiRT-PCR) for rapid and sensitive detection of classical swine fever virus. Transbound Emerg Dis 63: e395-402.

36. Ambagala A, Pahari S, Fisher M, Lee PA, Pasick J, et al. (2015) A rapid field-deployable reverse transcription-insulated isothermal polymerase chain reaction assay for sensitive and specific detection of bluetongue virus. Transbound Emerg Dis doi: 10.1111/tbed.12388.

37. Tung H-Y, Wang SH, Chiang YC, Tsai MS (2016) Rapid screening of roundup ready soybean in food samples by a hand-held PCR device. Food Sci Biotechnol 4: 1101-1107.

38. Lin YH, Lin YJ, Chang TD, Hong LL, Chen TY, et al. (2016) Development of a TaqMan probe-based insulated isothermal polymerase chain reaction (iiPCR) assay for detection of Fusarium oxysporum $\mathrm{f}$. sp. cubense Race 4. PLoS ONE 7: e0159681.

39. Chua KH, Lee PC, Chai HC (2016) Development of insulated isothermal PCR for rapid on-site malaria detection. Malaria $\mathrm{J} 1: 1$

40. Ambagala A, Fisher M, Goolia M, Nfon C, Furukawa-Stoffer T, et al. (2016) Field-deployable reverse transcription-insulated isothermal PCR (RT-iiPCR) assay for rapid and sensitive detection of foot-and-mouth disease virus. Transbound Emerg Dis doi: 10.1111/tbed.12554.

41. Zhang J, Tsai YL, Lee PYA, Chen Q, Zhang Y, et al. (2016) Evaluation of two singleplex reverse transcription-Insulated isothermal PCR tests and a duplex real-time RT-PCR test for the detection of porcine epidemic diarrhea virus and porcine deltacoronavirus. J Virol Methods 234: 34-42.

42. Soltan MA, Tsai YL, Lee PA, Tsai CF, Chang HG, et al. (2016) Comparison of electron microscopy, ELISA, real time RT-PCR and insulated isothermal RTPCR for the detection of Rotavirus group A (RVA) in feces of different animal species. J Virol Methods 235: 99-104.

43. Wilkes RP, Kania S, Tsai YL, Lee PY, Chang HH, et al. (2015) Rapid and sensitive detection of feline immunodeficiency virus using an insulated isothermal polymerase chain reaction-based assay with a point-of-need PCR detection platform. J Vet Diagn Invest 27: 510-515

44. Drigo M, Franzo G, Belfanti I, Martini M, Mondin A, et al. (2014) Validation and comparison of different end point and real time RT-PCR assays for detection and genotyping of porcine reproductive and respiratory syndrome virus. J Virol Methods 201: 79-85.

45. Tamura K, Peterson D, Peterson N, Stecher G, Nei M, et al. (2011) MEGA5 Molecular evolutionary genetics analysis using maximum likelihood evolutionary distance, and maximum parsimony methods. Mol Biol Evol 10 2731-2739.

46. Klungthong $C$, Chinnawirotpisan $P$, Hussem $K$, Phonpakobsin T, Manasatienki $\mathrm{W}$, et al. (2010) The impact of primer and probe-template mismatches on the sensitivity of pandemic influenza A/H1N1/2009 virus detection by real-time RTPCR. J Clin Virol 2: 91-95.

47. Gerber PF, Xiao CT, Cao D, Meng XJ, Opriessnig T (2014) Comparison of real- 
Citation: Kuo HC, Lo DY, Chen CL, Lee CH, Shen YH, et al. (2017) Rapid Detection of Type 2 Porcine Reproductive and Respiratory Syndrome Virus by a Duplex Reverse Transcription Insulated Isothermal PCR on a Field-Deployable System. J Vet Sci Technol 8: 415. doi: 10.4172/21577579.1000415

time reverse transcriptase PCR assays for detection of swine hepatitis $E$ virus in fecal samples. J Clin Microbiol 4: 1045-1051.
48. Rychlik W (2007) OLIGO 7 primer analysis software. Methods Mol Biol 402: 35-60.

49. Schrader C, Schielke A, Ellerbroek L, Johne R (2012) PCR inhibitors Occurrence, properties and removal. J Appl Microbiol 5: 1014-1026. 